\title{
光音響イメージングに用いる造影用ナノ粒子の設計指針
}

\author{
深澤 智典*
}

\section{Phenomenological Model for a Nanoparticle Design Strategy for Photoacoustic Contrast Imaging}

\author{
Tomonori Fukasawa*
}

\begin{abstract}
Photoacoustic (PA) imaging is one of the rapidly growing techniques for biomedical imaging because this noninvasive imaging technique combines the advantages of both optical and acoustic imaging techniques. The degree of contrast in PA imaging depends on the optical-to-acoustic conversion (optoacoustic) efficiency and can be exogenously improved by using nanoparticles (NPs) as contrast agents. With recent progress in nanotechnology, various NPs have been synthesized to serve as contrast agents. These studies focus on the improvement of absorption efficiency of light energy of the particles because the amplitude of PA signal increases with increasing absorption efficiency. Nevertheless, we have limited knowledge of the fundamental aspects of the photoacoustic phenomenon. This review presents our theoretical description of the PA pressure pulse from suspensions of NPs and some experimental results. The findings of our studies and the proposed phenomenological model provide a strategy for the design of NPs for PA contrast imaging.
\end{abstract}

Keywords: Photoacoustic imaging, Contrast agents, Nanoparticles, Phenomenological modeling, Particle design.

\section{1.はじめに}

光音響効果 (Photoacoustic effect) は, 1880 年に, 電話 の発明で有名な Alexander Graham Bell によって報告され た[1]。その後, ガスの濃度計測や固体試料の分光測定な どに応用され，光音響分光法 (Photoacoustic spectroscopy; PAS）として発展してきた。近年では，生体・医学分野 における診断やイメージング技術に応用され，光音響イ メージング (Photoacoustic imaging; PAI) として注目され ている。光音響イメージングは, 光のエネルギーを吸収 した部位から発生した音響波をとらえて可視化する技術 である。入力側が光, 出力側が音響波であり, 蛍光イメー ジング (Fluorescence imaging; FI) と超音波イメージング (Ultrasonography; US）の特徴を併せもつ。光の波長パラ メータを適切に設定することで, 特定の光吸収体を選択 的に励起・可視化できる。さらに, 光と比較して散乱や 吸収による減衰を受けにくい音響波を検出信号とするた め, 分解能および感度の悪化が生じず，生体深部まで高 い空間解像度が得られる[2,3]。

光音響イメージングでは, ナノ粒子を光エネルギーの 吸収体として用いることにより, 病変細胞を特異的に認 識する標的リガンドを粒子表面に修飾することで癌など

\footnotetext{
2018 年 2 月 5 日受付

広島大学大学院工学研究科 化学工学専攻

( ₹ 739-8527 東広島市鏡山 1-4-1)

Department of Chemical Engineering, Hiroshima University

(1-4-1 Kagamiyama, Higashihiroshima, Hiroshima 739-8527, Japan)

* Corresponding Author fukasawa@hiroshima-u.ac.jp
}

の腫瘍組織への集積や, 腫瘍周辺の血管に粒子径数十 $\mathrm{nm}$ から $200 \mathrm{~nm}$ のナノ粒子が集積する EPR 効果（Enhanced permeation and retention effect）の利用により, 腫瘍部位 を選択的に可視化できる $[4]$ 。本稿では, 現在提案されて いる代表的な造影用ナノ粒子とその設計指針を紹介する。

\section{2. 造影用ナノ粒子}

生体イメージングにおいて，造影用ナノ粒子にはより 細胞深部までのイメージングが可能となるよう, 生体透 過性の高い近赤外領域に吸収波長を有することが求めら れる[5]。

現在, 研究・開発が進められている造影用ナノ粒子は, その光エネルギーの吸収様式により, 表面プラズモン共 鳴（Surface Plasmon Resonance; SPR）を利用した粒子と, 色素を含有した粒子の 2 種類に分類される。

表面プラズモン共鳴を利用した造影粒子として，金ナ ノシェル[6], 金ナノロッド[7]が代表的である。これらの 粒子では, シェル厚みやアスペクト比の変更により吸収 波長を調整できるため, 同一材料での多色イメージング も可能である。また, 金ナノケージ[8]や単層カーボンナ ノチューブ（Single-walled carbon nanotubes; SWNTs）[9], 銀ナノシェル[10]の利用も検討されている。

色素含有粒子に用いられる色素分子としては, ICG （Indocyanine Green）が代表的である。ICGは, 近赤外領 域に吸収波長を有し, 生体適合性も認められていること から, 臨床応用に際し, 非常に有用な色素である。その ほかにも, Polymethine (Cy5.5, Cy7) や Alexa Fluor 750, IRDye78 などが用いられている。これらの色素を有機修 


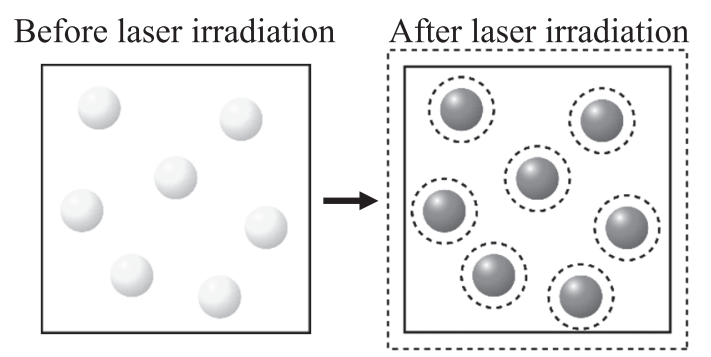

Fig. 1 Schematic representation of the monodispersed particle suspension before/after laser irradiation

(a)

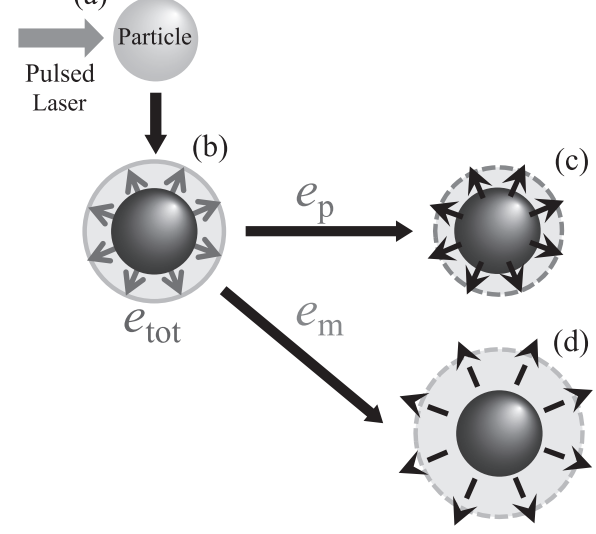

Fig. 2 Generation process of photoacoustic pulse: (a) laser irradiation, (b) heat generation and transfer into surrounding medium, (c) thermal expansion of particle, and (d) thermal expansion of medium

飾ケイ酸塩（Organically modified silica; ORMOSIL）やポ リ乳酸グリコール酸共重合体 (Poly lactic-co-glycolic acid; PLGA), リン酸カルシウム（Calcium phosphate）などの ナノ粒子に内包することにより，造影粒子として利用さ れる[11-13]。

これまでの造影用ナノ粒子の研究・開発では, おもに 光エネルギーの吸収効率の向上にその重きが置かれてい た。より強い音響波を発する優れた造影粒子の開発には, 光エネルギーから音響波への変換効率の向上も重要と なってくる。そのため, 粒子設計の更なる合理化へ向け て, 光音響波の発生メカニズムに基づく工学モデルの活 用が期待されている。

\section{3. 光音響信号強度を推算する工学モデル}

光音響波は光照射された領域内における粒子および粒 子周囲媒体それぞれの熱膨張によって発生する（Fig. 1)。 光エネルギーは粒子にて熱エネルギーに変換され, 粒子 の熱澎張を引き起こす。また，変換された熱エネルギー の一部は粒子の周囲媒体へ流出し, 媒体の熱膨張を引き 起こす (Fig. 2)。この光照射された領域内に生じる熱膨 張に起因する圧力変化 $p_{\text {tot }}$ を,「粒子寄与 $\left.p_{\mathrm{p}}\right\rfloor$ と「粒子周 囲媒体寄与 $p_{\mathrm{m}} 」$ の和として表現した以下のモデル式が提 案されている[14-16]。

$$
\begin{aligned}
& p_{\text {tot }}=n_{\mathrm{p}} e_{\text {tot }}\left[\frac{\kappa_{\mathrm{p}}}{\kappa_{\mathrm{m}}} \Gamma_{\mathrm{p}} \times x+\Gamma_{\mathrm{m}} \times(1-x)\right]=p_{\mathrm{p}}+p_{\mathrm{m}} \\
& \Gamma_{\mathrm{i}} \equiv \frac{\beta_{\mathrm{i}}}{\kappa_{\mathrm{i}} c_{\mathrm{i}} \rho_{\mathrm{i}}} \\
& x \equiv \frac{e_{\mathrm{p}}}{e_{\mathrm{tot}}}, 1-x \equiv \frac{e_{\mathrm{m}}}{e_{\mathrm{tot}}}, e_{\mathrm{tot}} \equiv e_{\mathrm{p}}+e_{\mathrm{m}}
\end{aligned}
$$

ここで, $n_{\mathrm{p}}$ は粒子数濃度, $\kappa$ は等温圧縮率, $\beta$ は熱膨張 係数, $c$ は比熱容量, $\rho$ は密度, $e$ はエネルギーである。 $\Gamma$ は Grüneisen 定数であり, 構成物質の熱膨張率と比熱な どの熱物性を反映した重要なパラメータである。添え字 tot, $\mathrm{p}, \mathrm{m}$ は, それぞれ全体, 粒子および粒子周囲媒体を 表す。 $x$ は光照射によって粒子 1 個が受け取る全熱エネ ルギー $e_{\mathrm{tot}}$ に対して粒子側に残るエネルギー $e_{\mathrm{p}}$ の割合で ある。Eq. (1) における圧力変化 $p_{\text {tot }}$ が信号強度に対応す る。また Eq. (1)より, 信号強度の増大には, Grüneisen 定数に代表される粒子および粒子周囲媒体の物性值のみ ならず，熱エネルギーの配分も重要となる。たとえば, $\left(\kappa_{\mathrm{p}} / \kappa_{\mathrm{m}}\right) \Gamma_{\mathrm{p}}>\Gamma_{\mathrm{m}}$ の場合, 粒子側により多く熱エネルギーが 残留することで信号強度が増大する。すなわち, 粒子の 熱閉じ込めが重要な課題となる。

\section{4. モデル粒子を用いた工学モデルの検証}

光音響波の発生メカニズムに基づき導出された工学モ デル（Eq. (1)）の妥当性の検証実験を紹介する。

\section{1 光音響信号}

光音響信号の測定装置の概略図を Fig. 3 に示す。ナノ 粒子懸濁液をキュベットに入れ, 温度調整した水槽中に 固定し, パルスレーザー光の照射により発生する光音響 信号をハイドロフォンにて測定する。異なる光路長を有 する 3 種類のキュベットを用いて測定した金ナノ粒子 (直 径 $8 \mathrm{~nm}$ ）懸濁液の光音響信号を Fig. 4 に示す[14]。いず れの光路長においても, 特徵的なピークが 2 力所見られ る。1つ目および 2 目のピークは, それぞれハイドロ フォン側 $(Z=L)$ とレーザー側 $(Z=0)$ において発生す る光音響信号に対応する。また，そのピーク間隔は光路 長を反映している。光音響信号強度は, レーザー光の減 衰を受けないレーザー側 $(Z=0)$ からの信号強度を採用 する。レーザー光および音響波の減衰に関する詳細な検 討については文献を参考されたい[14]。

\section{2 粒子数濃度（光学密度）と光音響信号強度}

粒子サイズが小さく光の散乱が無視でき, 照射された 光エネルギーのすべてが熱エネルギーとして粒子に吸収 されるならば, 単位体積あたりに受け取る総熱エネルギー $n_{\mathrm{p}} e_{\mathrm{tot}}$ は光学密度 $\mathrm{OD}_{\lambda}$ に比例する。

$$
n_{\mathrm{p}} e_{\mathrm{tot}} \propto \mathrm{OD}_{\lambda}
$$

Eqs. (1), (2) より, 信号強度は光学密度 $\mathrm{OD}_{\lambda}$ に比例する。 Fig. 5 に, 金ナノ粒子懸濁液について, 各光学密度（粒 子数濃度）における信号強度の測定結果を示す[15]。各 粒子サイズおよび懸濁液温度において, 信号強度は光学 
(a)

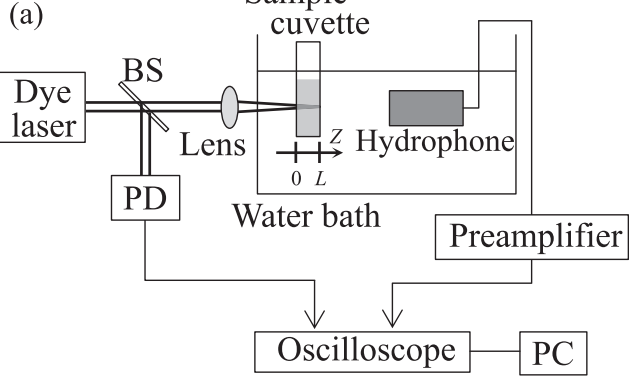

(b)

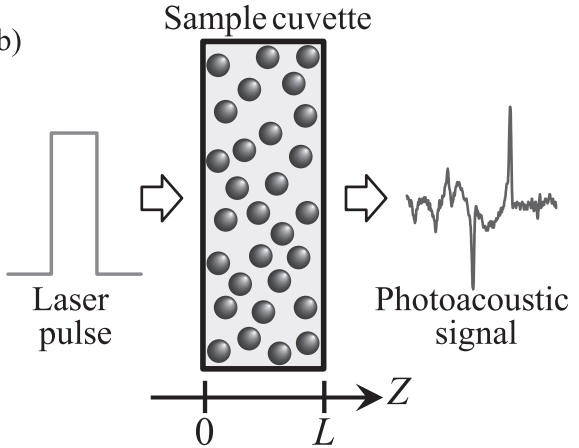

Fig. 3 (a) Illustration of the experimental setup. BS-beam splitter, PD-photodiode, $\quad \mathrm{PC}$-computer (b) Schematic representation of the photoacoustic pressure pulse from a laser-irradiated suspension of nanoparticles

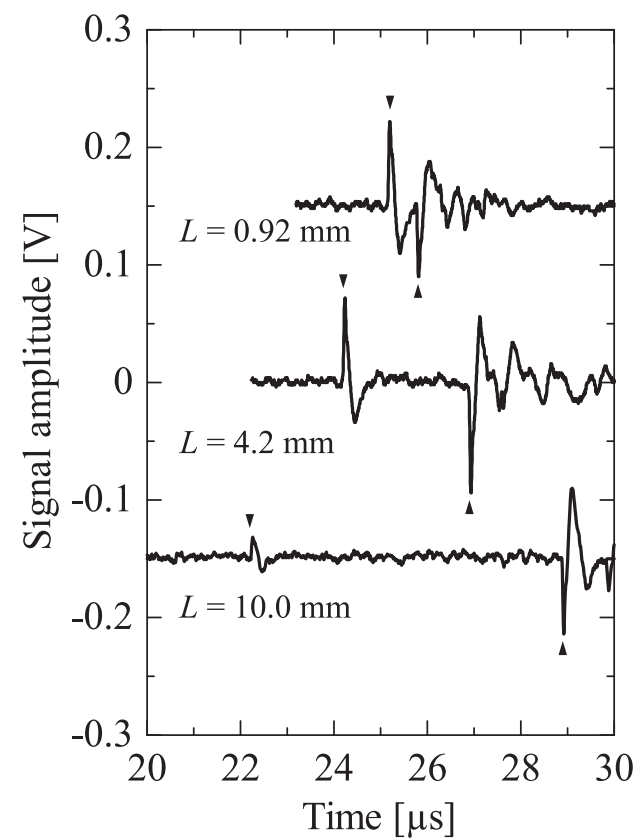

Fig. 4 Signal amplitudes observed from a laser-irradiated aqueous suspension of $8.0-\mathrm{nm} \mathrm{Au}$ nanospheres at $20^{\circ} \mathrm{C}$, as a function of time for different sample cuvettes: the light path length of $L=0.92,4.2$, and $10.0 \mathrm{~mm}$. The laser pulse width and wavelength were $0.8 \mathrm{~ns}$ and $509 \mathrm{~nm}$, respectively. The signals for $L=0.92$ and $10.0 \mathrm{~mm}$ are shifted from the original data by +0.15 and $-0.15 \mathrm{~V}$, respectively. The arrows indicated two isolated spikes observed.

密度に比例して増加した。この結果は提案された工学モ デル（Eq. (1)）と定性的に一致している。

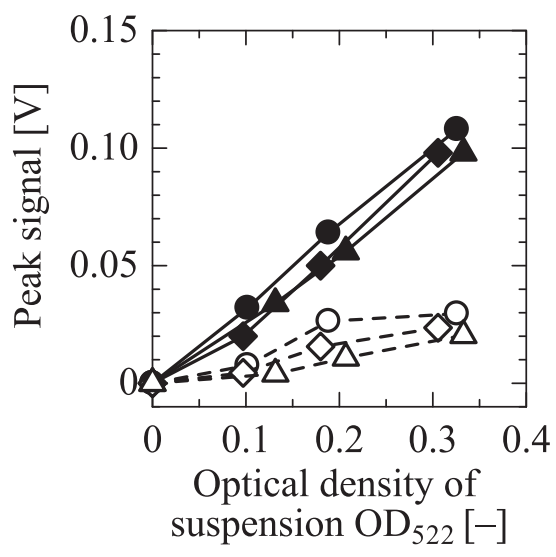

Fig. 5 The peak values of the signals observed from a laserirradiated aqueous of 19.9-nm (circles), 40.2-nm (diamonds), and 49.3-nm (triangles) Au nanoparticles, as a function of the optical density of suspension $\mathrm{OD}_{522}$ for different temperatures of $4^{\circ} \mathrm{C}$ (open symbols) and $20^{\circ} \mathrm{C}$ (filled symbols). The laser pulse width and wavelength were $0.8 \mathrm{~ns}$ and $522 \mathrm{~nm}$, respectively.

\section{3 粒子および粒子周囲媒体の物理化学特性と光音響 信号強度}

Eq. (1)より, 粒子懸濁液からの光音響信号強度の増大 には, 粒子および粒子周囲媒体の物理化学特性と熱エネ ルギーの配分が重要となる。ここで，金属系粒子の代表 例として金ナノ粒子を, 高分子系粒子の代表例として色 素（DiI）含有ポリスチレン（PS）ナノ粒子を用いたモデ ル実験を紹介する。

各懸濁液について, $20^{\circ} \mathrm{C}$ 抢よび $4{ }^{\circ} \mathrm{C}$ に打ける粒子直径 $d_{\mathrm{p}}$ と光音響信号強度の関係を Fig. 6 に示す $[16]$ 。ここで, 縦軸は測定された信号強度を光学密度 $\mathrm{OD}_{\lambda}$ にて規格化し た值を示す。Eqs. (1), (2)より, 以下の関係が成り立つ。

$$
\frac{p_{\text {tot }}}{\mathrm{OD}_{\lambda}} \propto \frac{p_{\text {tot }}}{n_{\mathrm{p}} e_{\text {tot }}}=\frac{\kappa_{\mathrm{p}}}{\kappa_{\mathrm{m}}} \Gamma_{\mathrm{p}} \times x+\Gamma_{\mathrm{m}} \times(1-x)
$$

Table 1 に $20^{\circ} \mathrm{C}$ および $4^{\circ} \mathrm{C}$ における各懸濁液の $\left(\kappa_{\mathrm{p}} / \kappa_{\mathrm{m}}\right) \Gamma_{\mathrm{p}}$ と $\Gamma_{\mathrm{m}}$ の值を示す。 $20^{\circ} \mathrm{C}$ に扔いて，金ナノ粒子懸濁液で は粒子直径の減少にともなって信号強度が増大した。 Table 1 より $\left(\kappa_{\mathrm{p}} / \kappa_{\mathrm{m}}\right) \Gamma_{\mathrm{p}}<\Gamma_{\mathrm{m}}$ であり, Eq. (3) から粒子周囲媒 体（水）へ熱エネルギーをより多く配分することにより 信号強度の増大が期待される。したがって, 粒子直径の 減少にともなう比表面積の増加によって, 粒子から粒子 周囲媒体への熱エネルギーの流出が促進され, 信号強度 が増大したと考えられる。一方, PS ナノ粒子懸濁液では 粒子直径の増加により信号強度が増大した。Table 1 より $\left(\kappa_{\mathrm{p}} / \kappa_{\mathrm{m}}\right) \Gamma_{\mathrm{p}}>\Gamma_{\mathrm{m}}$ であり, 粒子により多くの熱エネルギーを 閉じ込めることが信号強度の増大に効果的となる。すな わち, 粒子直径の増加による比表面積の減少により熱閉 じ込めが向上し，信号強度が増大したと考えられる。ま た， $4^{\circ} \mathrm{C}$ ではいずれの懸濁液においても粒子直径の増加

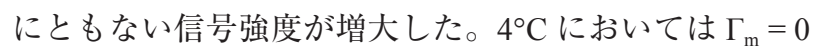
$\left(\because \beta_{\mathrm{m}}=0\right)$ となり, 信号強度は粒子寄与 $p_{\mathrm{p}}$ のみとなる。そ のため, 熱閉じ込めが向上する粒子直径の増加により信 

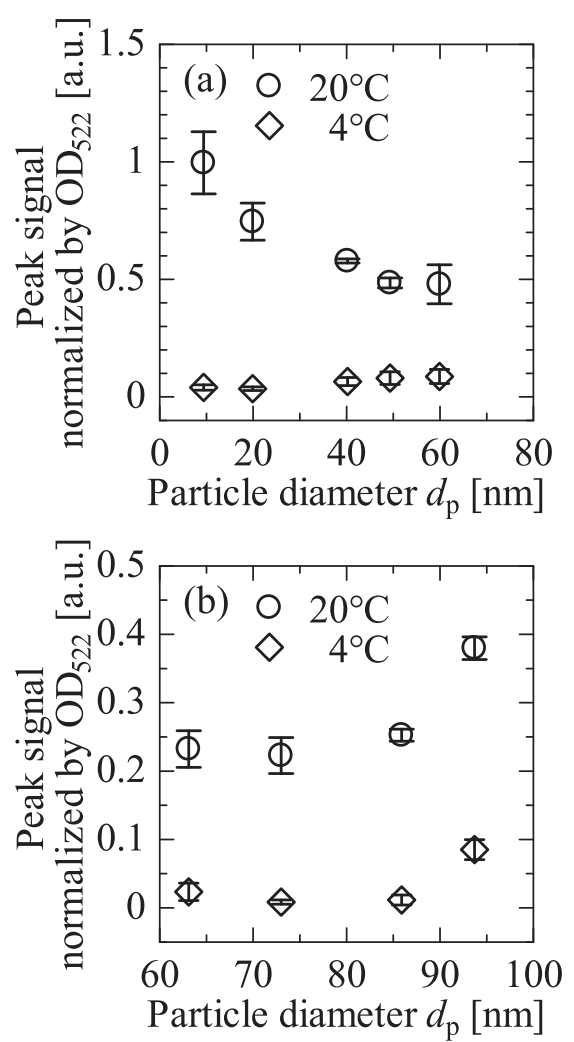

Fig. 6 The magnitude of photoacoustic response from a nanoparticle suspension at $20^{\circ} \mathrm{C}$ and $4{ }^{\circ} \mathrm{C}$, as a function of the nanoparticle diameter $d_{\mathrm{p}}$ : (a) $\mathrm{Au}$ and (b) PS nanoparticle. The data collected from the nanoparticle suspensions of three different concentrations were expressed as the mean \pm standard error of the mean. The laser pulse width and wavelength were $5 \mathrm{~ns}$ and $560 \mathrm{~nm}$, respectively.

号強度が増大した。以上より，工学モデルに基づく理論 予測と実験結果は良好な一致を示した。
Table 1 Physical properties of gold (Au) and polystyrene (PS) suspensions

\begin{tabular}{cccc}
\hline & & $\left(\kappa_{\mathrm{p}} / \kappa_{\mathrm{m}}\right) \Gamma_{\mathrm{p}}$ & $\Gamma_{\mathrm{m}}$ \\
\hline $\mathrm{Au}$ & $20^{\circ} \mathrm{C}$ & 0.038 & 0.108 \\
& $4{ }^{\circ} \mathrm{C}$ & 0.035 & 0 \\
$\mathrm{PS}$ & $20^{\circ} \mathrm{C}$ & 0.324 & 0.108 \\
& $4^{\circ} \mathrm{C}$ & 0.300 & 0 \\
\hline
\end{tabular}

\section{5. おわりに}

ナノ粒子の造粒技術の発達により, この数年で本稿で は取り上げきれないほどの多種多様な造影用ナノ粒子が 研究・開発されている。今後の更なる発展へ向け, 本稿 にて紹介した工学モデルが粒子設計指針の一助となれば 幸いである。

本稿では，イメージング技術に焦点を絞り，造影用粒 子のいくつかの例や設計指針となる工学モデルを紹介し た。今後, 臨床応用を視野に入れると, ナノ粒子の毒性 (ナノリスク) や生体適合性なども考慮に入れた研究が必 要不可欠となろう。また，応用技術としてレーザー照射 により多量の熱をナノ粒子から局所的に発生させ, 腫瘍 患部を焼き切る温熱療法（Thermal therapy）[17]などへの 展開も可能であり, 今後の発展が期待される研究分野で ある。

\section{[謝辞]}

工学モデルの導出・検証に際して, 多大なご指導・ご 鞭撻を賜りました福岡大学・新戸浩幸教授, 京都大学・ 大嶋正裕教授に心より感謝申し上げます。また，モデル 化に関する一連の研究は, 地域産学官連携科学技術振興 事業費補助金（高次生体イメージング先端テクノハブ） の一環として実施された。

\section{Nomenclature}

$c \quad:$ Specific heat capacity

$d_{\mathrm{p}}:$ Particle diameter

$e \quad:$ Thermal energy

$L \quad$ : Light path length

$n_{\mathrm{p}} \quad$ : Particle number concentration

$\mathrm{OD}_{\lambda}$ : Optical density

$p \quad$ : Pressure

$x$ : Ratio of the thermal energy remained inside the nanoparticle to the total thermal energy

$\left[1 / \mathrm{m}^{3}\right]$
$[\mathrm{J} /(\mathrm{kg} \cdot \mathrm{K})] \quad \beta \quad:$ Thermal coefficient of volume expansion

$[1 / \mathrm{K}]$

[m] $\quad \Gamma \quad:$ Grüneisen parameter

$[\mathrm{J}] \quad \kappa$ : Isothermal compressibility

[m] $\quad \rho \quad:$ Mass density

$\left[\mathrm{kg} / \mathrm{m}^{3}\right]$

Subscript

[Pa] $\mathrm{m}$ : Medium

$\mathrm{p}$ : Particle

tot : Total

\section{References}

[1] A. G. Bell, On the production and reproduction of sound by light, Am. J. Sci. 20 (1880) 305-324.

[2] L. V. Wang, S. Hu, Photoacoustic tomography: in vivo imaging from organelles to organs, Science 335 (2012) 1458-1462.

[3] S. Sato, M. Obara, Progress in light-ultrasound/pressure wave combined medical technology, Jpn. J. Optics 38 (2009) 288-297.
[4] D. Wu, L. Huang, M. S. Jiang, H. B. Jiang, Contrast Agents for photoacoustic and thermoacoustic imaging: a review, Int. J. Mol. Sci. 15 (2014) 23616-23639.

[5] J. C. Zhang, Z. Y. Qiao, P. P. Yang, J. Pan, L. Wang, H. Wang, Recent advances in near-infrared absorption nanomaterials as photoacoustic contrast agents for biomedical imaging, Chin. J. Chem. 33 (2015) 35-52.

[6] W. Lu, Q. Huang, G. Ku, X. Wen, M. Zhou, D. Guzatov, P. 
Brecht, R. Su, A. Oraevsky, L. V. Wang, C. Li, Photoacoustic imaging of living mouse brain vasculature using hollow gold nanospheres, Biomaterials 31 (2010) 2617-2626.

[7] P. P. Joshi, S. J. Yoon, W. G. Hardin, S. Emelianov, K. V. Sokolov, Conjugation of antibodies to gold nanorods through Fc portion: synthesis and molecular specific imaging, Bioconjug. Chem. 24 (2013) 878-888.

[8] C. Kim, E. C. Cho, J. Chen, K. H. Song, L. Au, C. Favazza, Q. Zhang, C. M. Cobley, F. Gao, Y. Xia, L. V. Wang, In vivo molecular photoacoustic tomography of melanomas targeted by bioconjugated gold nanocages, ACS Nano 4 (2010) 4559-4564.

[9] A. De La Zerda, C. Zavaleta, S. Keren, S. Vaithilingam, S. Bodapati, Z. Liu, J. Levi, B. R. Smith, T. J. Ma, O. Oralkan, Z. Cheng, X. Y. Chen, H. J. Dai, B. T. Khuri-Yakub, S. S. Gambhir, Carbon nanotubes as photoacoustic molecular imaging agents in living mice, Nat. Nanotechnol. 3 (2008) 557-562.

[10] K. Homan, J. Shah, S. Gomez, H. Gensler, A. Karpiouk, L. Brannon-Peppas, S. Emelianov, Silver nanosystems for photoacoustic imaging and image-guided therapy, J. Biomed. Opt. 15 (2010) 021316.

[11] K. Li, B. Liu, Polymer-encapsulated organic nanoparticles for fluorescence andphotoacoustic imaging, Chem. Soc. Rev. 43 (2014) 6570-6597.

[12] M. A. Hahn, A. K. Singh, P. Sharma, S. C. Brown, B. M. Moudgil, Nanoparticles as contrast agents for in-vivo bioimaging: current status and future perspectives, Anal. Bioanal. Chem. 399 (2011) 3-27.

[13] J. Yu, D. Javier, M. A. Yaseen, N. Nitin, R. Richards-
Kortum, B. Anvari, M. S. Wong, Self-assembly synthesis, tumor cell targeting, and photothermal capabilities of antibody-coated indocyanine green nanocapsules, J. Am. Chem. Soc. 132 (2010) 1929-1938.

[14] H. Shinto, T. Fukasawa, H. Aoki, S. Ito, M. Ohshima, Acoustic pressure pulses from laser-irradiated suspensions containing gold nanospheres in water: Experimental and theoretical study, Colloids. Surf. A 430 (2013) 51-57.

[15] T. Fukasawa, H. Shinto, H. Aoki, S. Ito, M. Ohshima, Sizedependent effect of gold nanospheres on the acoustic pressure pulses from laser-irradiated suspensions, Adv. Powder Technol. 25 (2014) 733-738.

[16] T. Fukasawa, S. Noguchi, H. Shinto, H. Aoki, S. Ito, M. Ohshima, Effects of physicochemical properties of particles and medium on acoustic pressure pulses from laser-irradiated suspensions, Colloids. Surf. A 487 (2015) 42-48.

[17] X. H. Huang, P. K. Jain, I. H. El-Sayed, M. A. El-Sayed, Plasmonic photothermaltherapy (PPTT) using gold nanoparticles, Lasers Med. Sci. 23 (2008) 217-228.

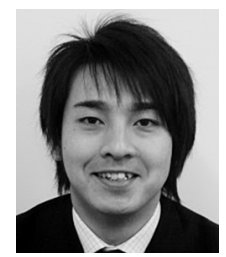

\section{深澤 智典}

〈著者紹介〉

2010 年 3 月 筑波大学大学院 生命環境科学 研究科 持続環境学専攻 博士後期課程修了, 2010 年 4 月 京都大学大学院 工学研究科 化学 工学専攻 特定研究員, 2014 年 11 月京都大学 大学院 工学研究科 化学工学専攻 特定助教, 2015 年 3 月 広島大学大学院 工学研究科 化学 工学専攻 助教, 現在に至る。博士 (環境学) 専門 : 粉体工学, コロイド界面化学, 界面動 電現象 